\title{
В.В. ДУБЕНСКИЙ
}

\section{К 55-ЛЕТИЮ \\ СО ДНЯ РОЖДЕНИЯ}

11 апреля 2011 года исполнилось 55 лет со дня рождения заведующего кафедрой кожных и венерических болезней Тверской государственной медицинской академии, доктора медицинских наук, профессора, Заслуженного врача РФ Валерия Викторовича Дубенского.

Валерий Викторович родился в 1956 году в г. Калинине. В 1978 г. окончил Калининский государственный медицинский институт и с 1979 года связал свою жизнь с дерматовенерологией, начав работу в должности районного дерматовенеролога центральной районной больницы в г. Лихославле Калининской области. Первый цикл обучения в 1981 г., в Казанском ГИДУВе под руководством к.м.н. Н.П. Емелиной, стал во многом знаковым, т. к. одним из приоритетных направлений работы Валерия Викторовича на десятилетия стала диагностика и лечение мужчин с воспалительными осложнениями урогенитальных инфекций, в т. ч. и в Калининском ОКВД, где Дубенский В.В. работал врачом- дерматовенерологом с 1981 по 1984 г.

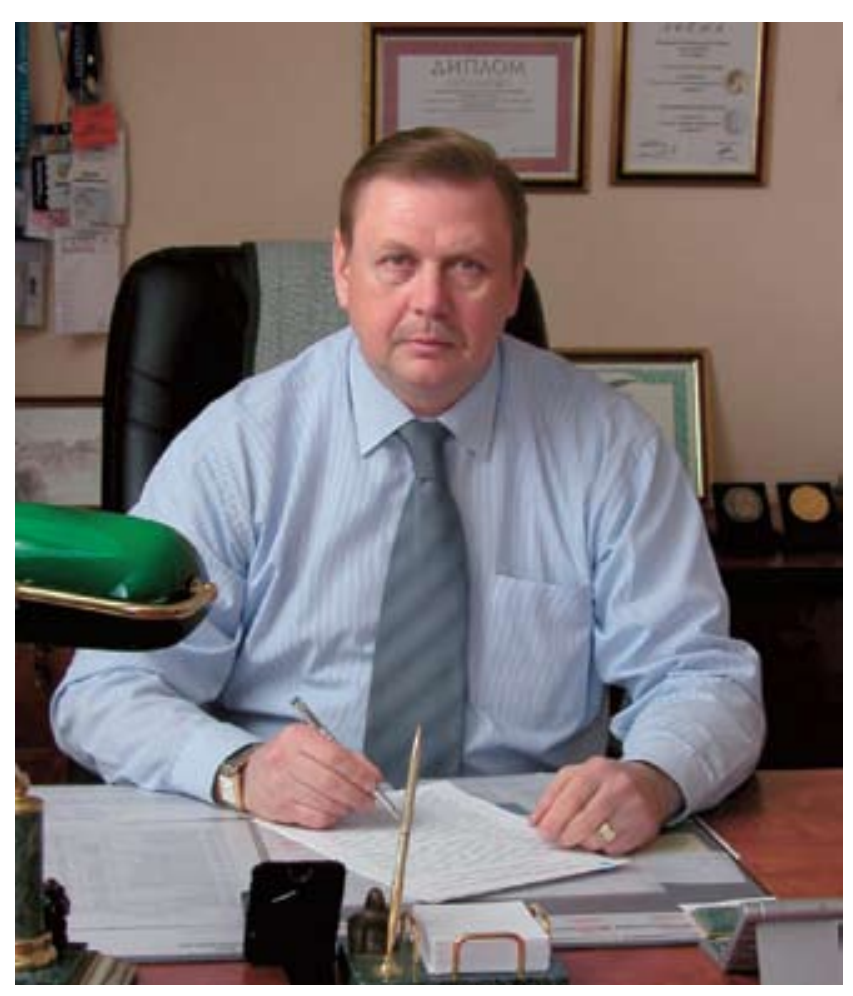

Необходимость расширения профессионального кругозора потребовала обучения в 1984-1986 гг. в клинической ординатуре при кафедре кожных и венерических болезней Калининского государственного медицинского института. Энергичность, склонность к научному поиску и профессионализм молодого врача привлекли внимание заведующего кафедрой профессора Юрия Михайловича Игошина, и с 1986 г. Валерий Викторович начал свою педагогическую и научную работу на кафедре, последовательно занимая должности ассистента и доцента (1993 г.), а в 1995 году — возглавил кафедру.

Первый этап научной деятельности Валерия Викторовича Дубенского завершился защитой в 1993 году кандидатской диссертации «Комплексное лечение хламидийных, гонорейно-хламидийных урогенитальных инфекций у мужчин лейкинфероном и фторхинолонами». Один из основных разделов научного исследования выполнен под руководством профессора В.В. Делекторского в отделении электронной микроскопии ЦНИкВИ. 
Итогом дальнейшей научной работы, посвященной изучению эпидемиологии, клиническому течению и иммунопатологии при ИППП и болезни Рейтера, была успешная защита докторской диссертации "Патогенетическое значение иммунологических нарушений в развитии осложненных урогенитальных инфекций и болезни Рейтера и их коррекция с помощью препаратов интерферона и цитокинов" в 1999 г., выполненной при научном консультировании чл.-корр. РАМН, д.м.н., профессора А.А. Кубановой и д.б.н., профессора В.П. Кузнецова. Большой раздел исследований был выполнен в отделениях НИИЭМ им. Н.Ф. Гамалеи, творческое и научное сотрудничество продолжается с 90-х годов.

В 1997 году Валерий Викторович Дубенский организовал при кафедре кожных и венерических болезней Тверской ГМА лечебно-диагностический и учебно-научный центр "Дерматолог", на базе которого в течение 9 лет проводилась лечебная и учебная и научная работа сотрудниками кафедры, а в 2002 году центр стал лауреатом почетной медали Е.Р. Дашковой (PAEH) «За практический вклад в оздоровление граждан России». В рамках гранта фонда Сореса, в 1998 году проведен первый сеанс телеконсультирования.

В 2005 году В.В. Дубенским открыта многопрофильная клиника ("Профессорская клиника»), в которой созданы условия для оказания высокотехнологической помощи населению по многим врачебным специальностям, включая дерматовенерологию и косметологию.

Дубенский Валерий Викторович вносит неоценимый вклад в развитие российской науки. На основании проводимых им исследований установлены современные особенности кардиоваскулярного и нейросифилиса, изучены вопросы иммунопатологии и ее коррекции при генитальном герпесе и папилломавирусной инфекции, эпидемиология и клинические особенности доброкачественных опухолей кожи. Внедрена в практику дерматовенерологии методика радиоволновой деструкции. Применение ирригационной уретроцистоскопии позволило доказа- тельно определять патологию мочеиспускательного канала при урогенитальных инфекциях.

Под руководством Валерия Викторовича защищено 9 кандидатских и выполняется 1 докторская диссертация. Дубенский В.В. автор 409 учебнометодических и научных работ, в том числе 3 монографий ("Нейросифилис", "Новообразования кожи в практике дерматовенеролога", «Урогенитальная папилломавирусная инфекция"), 5 руководств для врачей, 15 учебно-методических пособий с грифом «УМО». Коллективом сотрудников кафедры кожных и венерических болезней Тверской ГМА под руководством В.В. Дубенского в 1997 году были подготовлены первые в специальности пособия на электронных носителях: СД "LUES" и видеофильм “Сифилис".

В.В. Дубенский неоднократно рецензировал клинические рекомендации РОДВ и входил в авторские коллективы по подготовке протоколов ведения больных: гонорея, хламидиоз, трихомониаз.

С 2009 г. В.В. Дубенский - член Экспертного совета Профильной комиссии по дерматовенерологии и косметологии МЗ СР, принимал активное участие в подготовке «Порядка оказания медицинской помощи по профилю дерматовенерология», «Порядка оказания медицинской помощи по профилю косметология», «Программы дополнительного профессионального образования по косметологии", клинических рекомендаций "Атопический дерматит», «Простой герпес", "Опоясывающий герпес", "Акне».

Валерий Викторович Дубенский - член Европейской академии дерматовенерологии (EADV), Нью-Йоркской академии наук.

В качестве научного директора секции «Опухоли кожи" от Российского общества дерматовенерологов активно проводит подготовительную работу по проведению 2-го Континентального конгресса дерматовенерологов в г. Санкт-Петербурге 6-9/07.2011 г.

В.В. Дубенский в течение 10 лет был членом, далее заместителем председателя Проблемной учебнометодической комиссии по дерматовенерологии МЗРФ, член редакционной коллегии журнала «Вест- 
ник дерматологии и венерологии", член Ученого совета по защите докторских и кандидатских диссертаций (Д 208.1 15.01) при ФГУ «Государственный научный центр дерматовенерологии".

Профессор Дубенский В.В. возглавляет Тверское отделение и является членом правления Российского общества дерматовенерологов, награжден медалью РОДВ «За заслуги перед отечественной дерматовенерологией", в 2004 году ему присвоено почетное звание «Заслуженный врач РФ». За разработку инновационных способов лечения награжден золотой и серебряной медалями международной выставки инноваций “Архимед-2001»; награжден РАЕН почетной медалью И.И. Мечникова «За практический вклад в укрепление здоровья нации", нагрудным знаком губернатора «За заслуги в развитии Тверской области".

Валерий Викторович Дубенский обладает широким кругозором, высоким педагогическим мастерством, нравственными и деловыми качествами, блестящий лектор, пользуется заслуженным уважением дерматовенерологов России и свой юбилей встречает в расцвете творческих сил, полный энергии и научных планов.

Редакция журнала сердечно поздравляет юбиляра с днем рождения, желает ему здоровъя и больших творческих успехов. 